\title{
VASOMOTOR TONE IN THE PULMONARY VASCULAR BED IN PATIENTS WITH LEFT-TO-RIGHT SHUNTS*
}

\author{
BY \\ PETER A. M. AULD, JAMES E. GIBBONS, AND MAURICE McGREGOR \\ From the Joint Cardiorespiratory Service, Royal Victoria Hospital and the Montreal Children's Hospital, \\ Montreal, Canada \\ Received August 9, 1962
}

In the absence of increased vasomotor tone, increased pressure and flow on the pulmonary vascular bed should result in a reduction of pulmonary vascular resistance (Borst et al., 1956). In patients with left-to-right intracardiac shunts the frequent finding of values of pulmonary vascular resistance in the normal range thus implies the existence of increased vasomotor tone. If present, such tone should be capable of being reduced by drugs or oxygen breathing. The following study was designed to demonstrate the extent to which pulmonary vascular resistance could be lowered in these cases by the inhalation of pure oxygen.

\section{SubJeCtS AND Method}

The study concerns 20 children, 2 with a normal cardiovascular system and 18 with a congenital left-toright shunt lesion. All but 3 of these were uncomplicated ventricular septal defects. Age, body size, and diagnosis are shown in the Table.

The studies were carried out subsequent to routine diagnostic right heart catheterization; no patients were anæsthetized. Several of the youngest patients did not receive any premedication, while the majority received 'nembutal' and 'demerol' ( $2 \mathrm{mg}$./lb. i.m.) one to two hours before the procedure. Initially blood samples were withdrawn from the pulmonary artery, brachial or femoral artery, and right atrium, and pressures were recorded from the same sites and from the pulmonary artery wedge position. The patient was then given 99.6 per cent oxygen to breathe at a high flow rate through a mask of low dead space and after 10 minutes the observations were repeated.

Blood samples were analysed for oxygen content and capacity in duplicate by the manometric technique of Van Slyke and Neill. Pressure measurements were made by a Statham P23 D strain gauge placed at the level of the sternal notch. Mean pressures were obtained by electrical integration and were recorded on an Electronics for Medicine recorder. Several assumptions were necessary because of the size of the subjects. Oxygen consumption was predicted from the data of Rudolph and Cayler (1958), and assumed not to change during oxygen breathing. Calculations of flow were made according to the Fick principle, with the assumption that left atrial blood oxygen content was the same as systemic arterial oxygen content. In the two cases with the Eisenmenger syndrome left atrial oxygen content was assumed to be 95 per cent of capacity during the control observations. During oxygen breathing left atrial oxygen content in Case 19 (Table) was estimated at 0.92 vol. per cent over capacity, the average rise in arterial oxygen content observed in the nonEisenmenger subjects when breathing oxygen. Pulmonary wedge pressure was not measured during the test period and was assumed to be unchanged from the value obtained immediately before the study. Resistance was calculated from the formula

$$
\frac{\mathrm{PA}(\mathrm{m})-\mathrm{LA}(\mathrm{m}) \text { or PV }(\mathrm{m})}{\dot{\mathrm{Qp}}}
$$

where $\dot{\mathrm{Q}} \mathrm{p}=$ pulmonary flow $1 . / \mathrm{min} . / \mathrm{m} .{ }^{2}$, and PA(m), LA(m), and PV(m) are mean pulmonary artery, left atrial, and pulmonary wedge pressures respectively, measured in $\mathrm{mm} . \mathrm{Hg}$.

\footnotetext{
* Supported by Health Research Grant No. 604-13-39.
} 
TABLE

Age, Body Size, Diagnosis, and Hemodynamic Data

\begin{tabular}{|c|c|c|c|c|c|c|c|c|c|c|c|c|c|c|c|c|}
\hline \multirow{3}{*}{$\begin{array}{l}\text { Case } \\
\text { No. }\end{array}$} & \multirow{3}{*}{$\begin{array}{c}\text { Age and } \\
\text { diagnosis }\end{array}$} & \multirow{3}{*}{$\begin{array}{c}\text { Body } \\
\text { size } \\
\text { area } \\
\left(\mathrm{m} .^{2}\right)\end{array}$} & \multicolumn{5}{|c|}{ Pressures (mm.Hg) } & \multicolumn{4}{|c|}{ Flow $\left(1 . / \mathrm{min} . / \mathrm{m}^{2}{ }^{2}\right)$} & \multicolumn{4}{|c|}{$\begin{array}{c}\text { Resistance } \\
\left(\mathrm{mm} . \mathrm{Hg} / \mathrm{l} . / \mathrm{min} . / \mathrm{m} .{ }^{2}\right)\end{array}$} & \multirow{3}{*}{$\begin{array}{c}\text { Systemic } \\
\text { arterial } \\
\text { satura- } \\
\text { tion } \\
(\%)\end{array}$} \\
\hline & & & \multirow{2}{*}{$\begin{array}{l}\text { Mean } \\
\text { PC or } \\
\text { LA }\end{array}$} & \multicolumn{2}{|c|}{ P.A. } & \multicolumn{2}{|c|}{ S.A. } & \multicolumn{2}{|c|}{$\dot{Q} p$} & \multicolumn{2}{|c|}{$\dot{\mathrm{Qs}}$} & \multicolumn{2}{|c|}{ Pulmonary } & \multicolumn{2}{|c|}{ Systemic } & \\
\hline & & & & Air & Oxygen & Air & Oxygen & Air & Oxygen & Air & Oxygen & Air & Oxygen & Air & Oxygen & \\
\hline 1 & Normal 10 yr. & $\overline{1 \cdot 28}$ & 8 & $22 / 10$ & $17 / 10$ & $\begin{array}{c}136 / 97 \\
(117)\end{array}$ & $\begin{array}{c}126 / 88 \\
(107)\end{array}$ & $4 \cdot 6$ & $4 \cdot 7$ & $4 \cdot 6$ & $4 \cdot 7$ & $1 \cdot 5$ & $1 \cdot 3$ & 25 & 22 & $98 \cdot 1$ \\
\hline 2 & $\begin{array}{l}\text { Mongol normal } \\
3 \text { wk. }\end{array}$ & 0.22 & 3 & $\begin{array}{l}32 / 5 \\
(16)\end{array}$ & $\begin{array}{l}30 / 6 \\
(18)\end{array}$ & $\begin{array}{l}60 / 36 \\
(50)\end{array}$ & (60) & $5 \cdot 0$ & $5 \cdot 5$ & $5 \cdot 0$ & $5 \cdot 5$ & $2 \cdot 6$ & $2 \cdot 7$ & 9 & 10 & $97 \cdot 0$ \\
\hline 3 & $\begin{array}{l}\text { A-V communis } \\
18 \mathrm{mo} \text {. }\end{array}$ & 0.33 & 2 & $\begin{array}{l}64 / 16 \\
(36)\end{array}$ & $\begin{array}{l}52 / 8 \\
(27)\end{array}$ & $\begin{array}{l}79 / 43 \\
(60)\end{array}$ & $\begin{array}{l}74 / 46 \\
(60)\end{array}$ & $13 \cdot 5$ & $14 \cdot 0$ & 一 & 一 & $2 \cdot 5$ & $1 \cdot 8$ & - & - & $98 \cdot 4$ \\
\hline 4 & $\begin{array}{l}\text { Coarctation of } \\
\text { aorta PDA } \\
3 \text { mo. }\end{array}$ & $0 \cdot 29$ & $5^{*}$ & $\begin{array}{l}67 / 27 \\
(51)\end{array}$ & $\begin{array}{l}47 / 17 \\
(31)\end{array}$ & $\begin{array}{l}74 / 43 \\
(62)\end{array}$ & $\begin{array}{l}78 / 51 \\
(61)\end{array}$ & $4 \cdot 7$ & $36 \cdot 0$ & - & - & $9 \cdot 8$ & 0.7 & - & - & $92 \cdot 0$ \\
\hline 5 & VSD $19 \mathrm{mo}$ & 0.42 & 8 & $\begin{array}{l}62 / 12 \\
(35)\end{array}$ & $\begin{array}{l}57 / 10 \\
(31)\end{array}$ & $\begin{array}{l}83 / 49 \\
(62)\end{array}$ & $\begin{array}{l}83 / 49 \\
(62)\end{array}$ & $13 \cdot 2$ & $18 \cdot 0$ & $3 \cdot 7$ & $3 \cdot 8$ & $2 \cdot 1$ & $1 \cdot 3$ & 17 & 17 & $92 \cdot 0$ \\
\hline 6 & VSD $18 \mathrm{mo}$. & 0.46 & 6 & $\begin{array}{l}32 / 8 \\
(21)\end{array}$ & $\begin{array}{l}26 / 3 \\
(17)\end{array}$ & $\begin{array}{l}84 / 55 \\
(75)\end{array}$ & & $8 \cdot 5$ & $7 \cdot 8$ & 一 & - & $1 \cdot 8$ & $1 \cdot 4$ & - & 一 & $96 \cdot 5$ \\
\hline 7 & VSD 14 yr. & $1 \cdot 26$ & 13 & $\begin{array}{l}69 / 32 \\
(44)\end{array}$ & $\begin{array}{l}51 / 17 \\
(33)\end{array}$ & $\begin{array}{c}106 / 69 \\
(83)\end{array}$ & $\begin{array}{c}101 / 70 \\
(84)\end{array}$ & $10 \cdot 7$ & $25 \cdot 9$ & $5 \cdot 1$ & $5 \cdot 2$ & $2 \cdot 9$ & 0.8 & 16 & 16 & $95 \cdot 0$ \\
\hline 8 & VSD $49 / 12$ yr. & 0.60 & 11 & $\begin{array}{l}67 / 18 \\
(42)\end{array}$ & $\begin{array}{l}62 / 13 \\
(37)\end{array}$ & $\begin{array}{c}106 / 56 \\
(76)\end{array}$ & $\begin{array}{c}108 / 73 \\
(88)\end{array}$ & 13.4 & $14 \cdot 8$ & $4 \cdot 6$ & 4.9 & $2 \cdot 3$ & $1 \cdot 8$ & 16 & 17 & $97 \cdot 0$ \\
\hline 9 & VSD 5 yr. & 0.65 & 7 & $\begin{array}{l}45 / 7 \\
(25)\end{array}$ & $\begin{array}{l}39 / 6 \\
(22)\end{array}$ & $\begin{array}{c}114 / 66 \\
(88)\end{array}$ & $\begin{array}{c}104 / 64 \\
(78)\end{array}$ & $8 \cdot 7$ & $11 \cdot 3$ & $3 \cdot 6$ & $3 \cdot 7$ & $2 \cdot 1$ & $1 \cdot 3$ & 24 & 21 & $97 \cdot 0$ \\
\hline 10 & VSD 2 yr. & 0.44 & 12 & $\begin{array}{l}80 / 29 \\
(54)\end{array}$ & $\begin{array}{l}67 / 16 \\
(33)\end{array}$ & $\begin{array}{l}92 / 50 \\
(66)\end{array}$ & $\begin{array}{l}93 / 47 \\
(64)\end{array}$ & 13.6 & $22 \cdot 8$ & $4 \cdot 2$ & $3 \cdot 5$ & $3 \cdot 1$ & 0.9 & 16 & 20 & 96.9 \\
\hline 11 & VSD $7 \mathrm{mo}$. & 0.34 & 6 & $\begin{array}{l}69 / 38 \\
(52)\end{array}$ & $\begin{array}{l}59 / 18 \\
(33)\end{array}$ & $\begin{array}{l}93 / 48 \\
(66)\end{array}$ & $\begin{array}{l}88 / 46 \\
(65)\end{array}$ & 9.9 & $11 \cdot 4$ & $4 \cdot 7$ & 3.0 & $4 \cdot 6$ & $2 \cdot 4$ & 14 & 22 & $97 \cdot 8$ \\
\hline 12 & VSD $46 / 12$ yr. & 0.64 & 11 & $\begin{array}{l}60 / 25 \\
(42)\end{array}$ & $\begin{array}{l}47 / 20 \\
(29)\end{array}$ & $(69)$ & (74) & $29 \cdot 0$ & 40.0 & $5 \cdot 4$ & $4 \cdot 3$ & $1 \cdot 1$ & $0 \cdot 2$ & 12 & 17 & $91 \cdot 0$ \\
\hline 13 & VSD $17 \mathrm{mo}$. & 0.5 & 6 & $\begin{array}{l}77 / 29 \\
(56)\end{array}$ & $\begin{array}{l}64 / 13 \\
(42)\end{array}$ & $\begin{array}{l}86 / 50 \\
(67)\end{array}$ & $\begin{array}{l}90 / 53 \\
(65)\end{array}$ & $9 \cdot 8$ & $18 \cdot 0$ & $3 \cdot 5$ & $4 \cdot 4$ & $5 \cdot 1$ & $1 \cdot 8$ & 19 & 15 & $97 \cdot 5$ \\
\hline 14 & VSD 3 yr. & 0.59 & 15 & $\begin{array}{l}76 / 26 \\
(50)\end{array}$ & $\begin{array}{l}63 / 15 \\
(38)\end{array}$ & (63) & $\begin{array}{l}82 / 55 \\
(65)\end{array}$ & $15 \cdot 3$ & $25 \cdot 7$ & 一 & - & $2 \cdot 3$ & 0.7 & - & - & $92 \cdot 2$ \\
\hline 15 & PDA + M.I. 4 yr. & 0.50 & 10 & $\begin{array}{l}90 / 29 \\
(56)\end{array}$ & $\begin{array}{l}73 / 18 \\
(47)\end{array}$ & $\begin{array}{l}98 / 28 \\
(62)\end{array}$ & $\begin{array}{l}92 / 24 \\
(54)\end{array}$ & $5 \cdot 4$ & $5 \cdot 8$ & $3 \cdot 7$ & $3 \cdot 5$ & $8 \cdot 5$ & $6 \cdot 4$ & 16 & 15 & $92 \cdot 0$ \\
\hline 16 & VSD $22 \mathrm{mo}$. & 0.54 & 5 & $\begin{array}{l}94 / 49 \\
(63)\end{array}$ & $\begin{array}{l}87 / 35 \\
(56)\end{array}$ & $\begin{array}{l}98 / 51 \\
(66)\end{array}$ & $\begin{array}{l}94 / 55 \\
(64)\end{array}$ & $7 \cdot 4$ & $14 \cdot 3$ & $4 \cdot 6$ & 3.4 & $8 \cdot 2$ & $3 \cdot 8$ & 14 & 19 & $92 \cdot 0$ \\
\hline 17 & VSD $16 / 12$ yr. & 0.52 & 17 & $\begin{array}{l}94 / 53 \\
(70)\end{array}$ & $\begin{array}{l}80 / 40 \\
(63)\end{array}$ & (70) & (77) & $16 \cdot 1$ & $11 \cdot 3$ & $4 \cdot 3$ & $3 \cdot 8$ & $3 \cdot 3$ & 4.0 & 16 & 20 & $94 \cdot 0$ \\
\hline 18 & VSD 6 yr. & $0 \cdot 70$ & 2 & $\begin{array}{l}62 / 31 \\
(47)\end{array}$ & $\begin{array}{l}69 / 33 \\
(49)\end{array}$ & (67) & (85) & $8 \cdot 3$ & $8 \cdot 1$ & $2 \cdot 9$ & $3 \cdot 0$ & $5 \cdot 5$ & $5 \cdot 8$ & 24 & 29 & $91 \cdot 0$ \\
\hline 19 & $\begin{array}{l}\text { VSD } \\
\text { Eisenmenger }\end{array}$ & 1.02 & 3 & $\begin{array}{c}102 / 60 \\
(76)\end{array}$ & $\begin{array}{c}100 / 56 \\
(74)\end{array}$ & $\begin{array}{c}106 / 72 \\
(88)\end{array}$ & $\begin{array}{c}100 / 72 \\
(84)\end{array}$ & $3 \cdot 6 \dagger$ & $5 \cdot 2 \ddagger$ & $4 \cdot 5+$ & $3 \cdot 7 \ddagger$ & 20.0 & $14 \cdot 0$ & 20 & 22 & $84 \cdot 7$ \\
\hline 20 & $\begin{array}{l}\text { VSD } \\
\text { Eisenmenger } \\
112 / 12 \text { yr. }\end{array}$ & 0.98 & 0 & $\begin{array}{l}85 / 50 \\
(69)\end{array}$ & $\begin{array}{c}103 / 45 \\
(71)\end{array}$ & $\begin{array}{l}97 / 67 \\
(82)\end{array}$ & $\begin{array}{l}97 / 67 \\
(82)\end{array}$ & $3.4 \dagger$ & 5.5 & $2 \cdot 9 \dagger$ & $3 \cdot 1$ & 20.0 & 12.9 & 28 & 27 & 92.0 \\
\hline
\end{tabular}

\section{RESULTS}

In the control period while breathing room air, 8 children had pulmonary vascular resistance values below $3 \mathrm{~mm} . \mathrm{Hg} / \mathrm{l} . / \mathrm{min} . / \mathrm{m} .{ }^{2}$. In 8 others there was a moderate rise in pulmonary vascular resistance $\left(3-10 \mathrm{~mm} . \mathrm{Hg} / \mathrm{l} . / \mathrm{min} . / \mathrm{m} .{ }^{2}\right)$ and in 2 with the Eisenmenger syndrome resistance was estimated at $20 \mathrm{~mm} . \mathrm{Hg} / \mathrm{l} . / \mathrm{min} . / \mathrm{m} .^{2}$ (Table).

On oxygen breathing no consistent change was observed in systemic pressure or flow. By contrast there was a small or moderate fall in PA pressure associated with an increase in pulmonary flow in many instances (Fig. 1). This resulted in a fall in calculated pulmonary vascular resistance (Fig. 2) in 16 out of the 18 cases with left-to-right shunts: this fall exceeded 20 per cent of control in 15 subjects and 50 per cent of the control in 6 subjects. The two subjects with the Eisenmenger syndrome showed a 30 and a 35 per cent fall in pulmonary vascular resistance, observable solely as an increase in pulmonary flow. In two normal subjects this value was substantially unchanged.

To avoid the error inherent in the prediction of oxygen consumption as well as the assumption that this was the same during air and oxygen breathing the ratio of pulmonary to systemic flow was calculated (Fig. 3a). This showed a rise in 12 of the 14 instances in which it could be calculated, and this rise exceeded 30 per cent of control value in eight instances. The ratio of pulmonary to systemic resistance (Fig. 3b) was calculated for a similar reason and showed a fall in the 14 patients in which it could be calculated. In 11 of these the fall exceeded 20 per cent of control, and in 6 cases 50 per cent of control. 

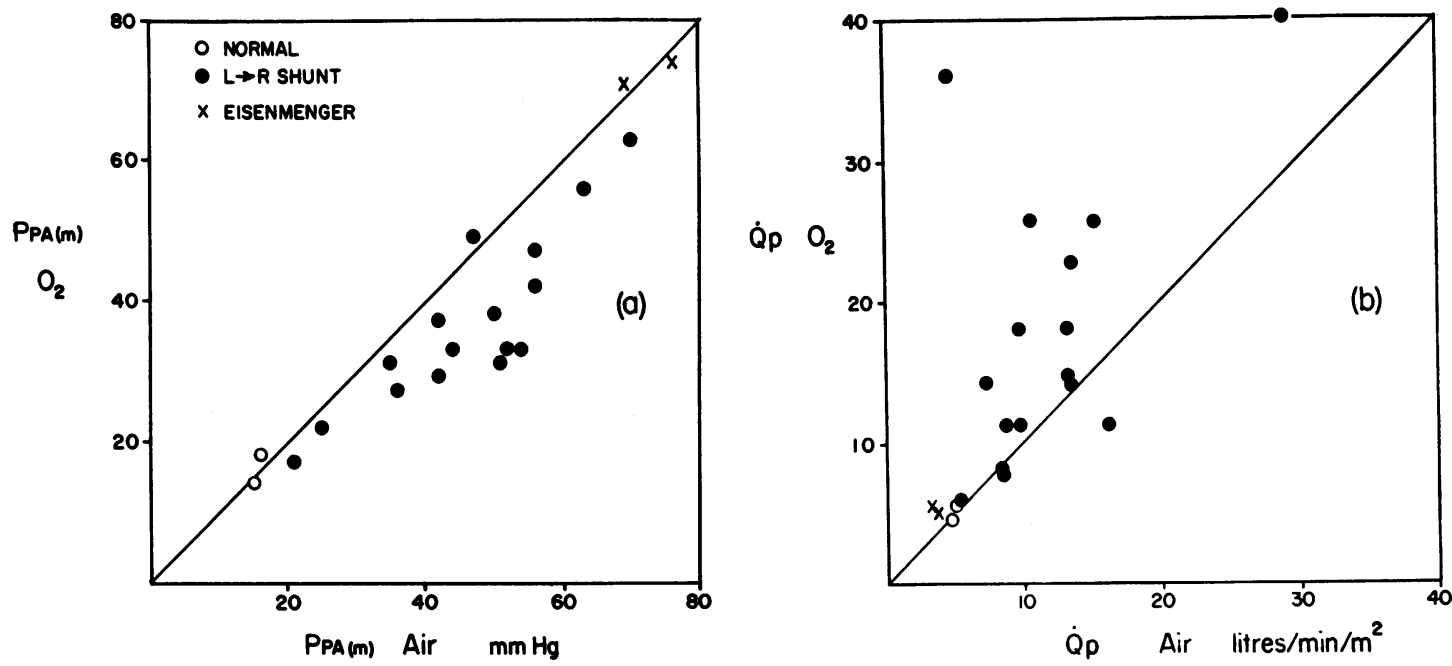

Fig. 1.-(a) Pulmonary arterial mean pressure during control period related to the pressure during oxygen breathing (b) Pulmonary flow while breathing air related to pulmonary flow on oxygen breathing.

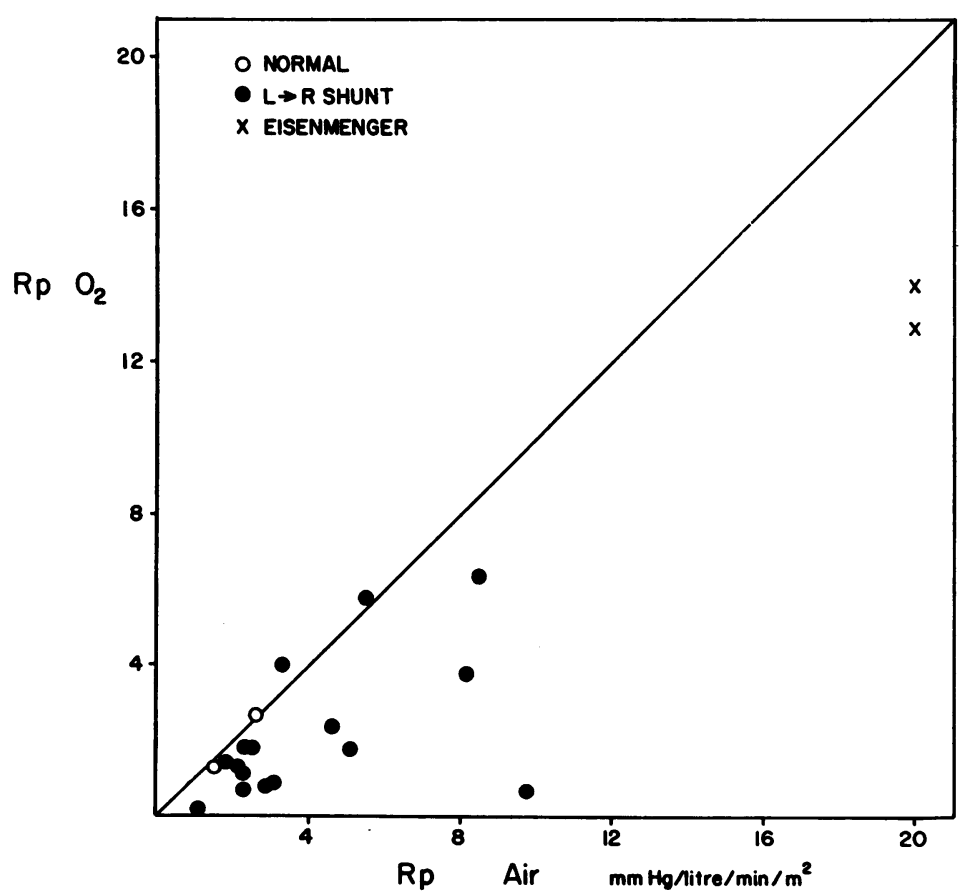

Fig. 2.-Pulmonary vascular resistance during air and oxygen breathing. 

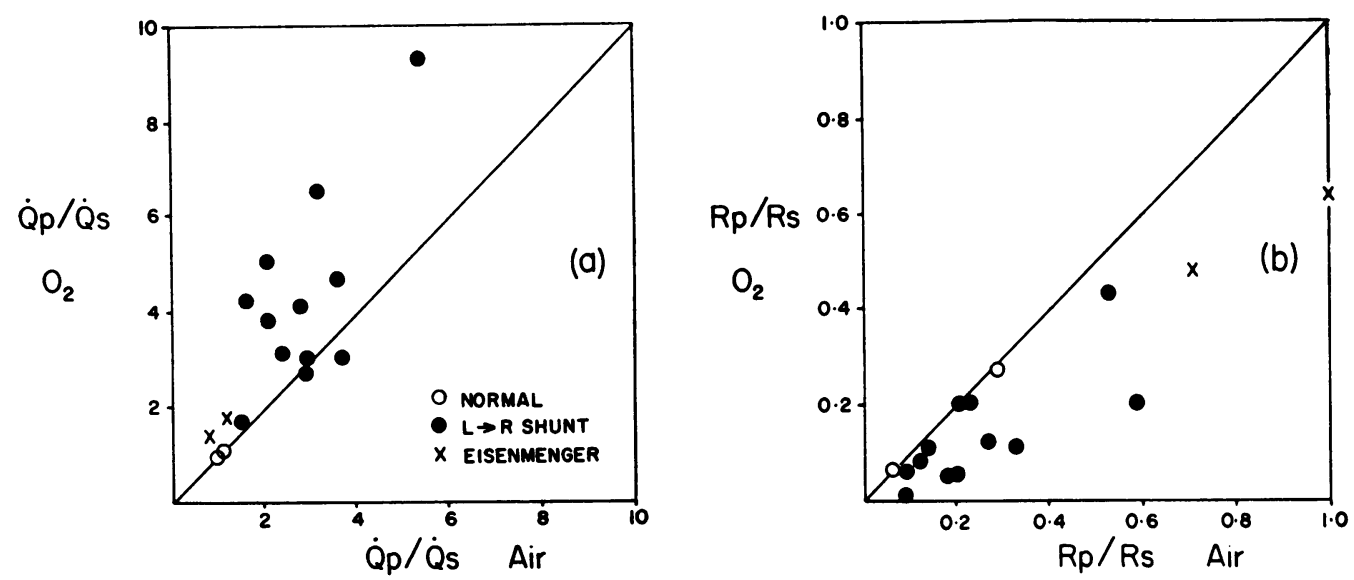

FIG. 3.-(a) Ratio of pulmonary flow to systemic flow during air and oxygen breathing. (b) Ratio of pulmonary to systemic resistance during air and oxygen breathing.

\section{Discussion}

There are several potential sources of error in this study, including the assumption that both left atrial pressure and oxygen uptake were unchanged during oxygen breathing. Justification of the former is the experience of Marshall et al. (1961) who observed no significant change in mean pulmonary artery wedge pressure in a similar group of subjects on changing from air to oxygen breathing. The same authors, however, did find a 5 per cent increase in oxygen uptake during oxygen administration. The pulmonary flow increase on oxygen breathing may thus have been proportionately underestimated in the present study. However, the alterations shown in pulmonary to systemic flow and resistance ratios could not have been subject to this source of error. Another potential source of error in the computation of flow data lies in the assumption that the samples withdrawn at right atrial and pulmonary arterial sites represent true mixed samples. Error due to incomplete mixing may well have influenced some studies. They should, however, have a random effect on the results obtained and could not possibly account for the trend towards increased pulmonary flow on oxygen breathing. The desirability of attempting the measurement of pulmonary flow as well as pressure is well illustrated by the two cases with the Eisenmenger syndrome. Administration of oxygen failed to change pulmonary artery pressure in either patient but in both a substantial change in flow was calculated, indicating a degree of reversibility of the high resistance that would not have been otherwise suspected.

The normal pulmonary vascular resistance is generally considered to be between 1 and $3 \mathrm{~mm} . \mathrm{Hg} / \mathrm{l} . / \mathrm{min} . / \mathrm{m} .^{2}$. It is perhaps somewhat surprising that patients with large left-to-right interventricular shunts, as many of these patients had, did not have subnormal resistance. If there were no changes in vascular tone with increased flow, vascular resistances should be lower by passive dilatation as has been shown in the perfused dog lung (Borst $e$ t al., 1956). Thus the present patients appeared to have a varying but considerable degree of increased tone that was capable of being abolished by oxygen breathing. The reason for this increase in pulmonary vascular tone in these patients is not clear. Increases in pulmonary resistance in the presence of anoxia, first inferred by Von Euler and Liljestrand (1946), are at least partly a direct effect of hypoxia on the pulmonary vascular bed (Borst et al., 1956). It is possible that a fall in resistance that occurs with oxygen breathing in patients with lung disease and in subjects with mitral stenosis (McGregor et al., 1953) is the result of correction of anoxia. Such an explanation in these subjects appears at first unlikely in view of the normal arterial saturations observed (Table), though it is possible that measurements of pulmonary venous oxygen tension would demonstrate abnormality. Disturbance of ventilationperfusion ratio resulting in localized areas of hypoxia with consequent increase in resistance in these 
areas might well be present in these subjects without detectable anoxæmia. Thus the more effectively flow is reduced by vasomotion in areas of reduced ventilation, the lower will be the mean alveolar arterial oxygen gradient. Furthermore such areas of raised resistance might be expected to have a much more measurable effect on the average vascular resistance across the lung in these subjects without a large reserve of pulmonary vascular bed. Relief of localized areas of hypoxia in the lung still seems the most likely explanation for the fall in resistance that was observed in these patients while breathing oxygen.

The effect of oxygen breathing observed here has been reported in the past in the presence of initially increased pulmonary vascular resistances (Burchell, Swann, and Wood, 1953; Swann, Burchell, and Wood, 1959). It has been less well documented, however, in patients whose increased pulmonary flow was associated with resistance values in the normal range. Wood (1959) was able to demonstrate a $5 \mathrm{~mm} . \mathrm{Hg}$ drop in pulmonary artery pressure in 2 or 3 patients with "hyperkinetic pulmonary hypertension" following the administration of acetylcholine. In a recent study of the effect of oxygen breathing in ventricular septal defect by Marshall et al. (1961) there were 8 subjects with initial values of total pulmonary resistance below 400 dynes $/ \mathrm{sec} . / \mathrm{cm} .^{-5}$ with a significant fall of resistance on oxygen breathing in 2 of these. The largest and most consistent reductions in pulmonary vascular resistance were reported by Voridis et al. (1959) who by simultaneous use of oxygen with hexamethonium or arfonad produced a fall in resistance in all of 7 subjects with left-toright intracardiac shunts in whom initial resistance values were within normal limits. The present data therefore are in general consistent with the findings of these workers and serve to substantiate them.

Finally it should be remarked that the presumption of increased vasomotor tone in subjects with increased pulmonary flow and normal pulmonary resistance is a logical extension of what is known of the pressure flow characteristics of the pulmonary vascular bed. Paul Wood (1959) has pointed out that "hyperkinetic pulmonary hypertension can only occur if the pulmonary vascular resistance fails to drop in response to increased flow". This failure of resistance to drop implies active vasomotion, the presence of which was confirmed by this study.

\section{SUMMARY}

Increased vasomotor tone in the pulmonary vascular bed of children with congenital left-to-right shunts has been evaluated by studying the effect of pure oxygen breathing on pulmonary vascular resistance. A number of the subjects studied had resistance values in the "normal" range that were further reduced by hyperoxia. This implies active vasomotion even in these subjects. It is suggested that a probable explanation for such increased vasomotor tone is an alteration of the ventilationperfusion ratio in the lung.

The technical assistance of Miss N. Corbeil is gratefully acknowledged.

\section{REFERENCES}

Borst, H. G., McGregor, M., Whittenberger, J. L., and Berglund, E. (1956). Circulat. Res., 4, 393.

Burchell, H. B., Swann, H. J. C., and Wood, E. H. (1953). Circulation, 8, 681.

McGregor, M., Bothwell, T. H., Zion, M. M., and Bradlow, B. A. (1953). Amer. Heart J., 46, 187.

Marshall, H. W., Swann, H. J. C., Burchell, H. B., and Wood, E. H. (1961). Circulation, 23, 241.

Rudolph, A. M., and Cayler, G. C. (1958). Pediat. Clin. N. Amer., 5, 907.

Swann, H. J. C., Burchell, H. B., and Wood, E. H. (1959). Circulation, 20, 66.

Von Euler, U. S., and Liljestrand, G. (1946). Acta physiol. scand., 12, 301.

Voridis, E., Scebat, L., Renais, J., and Lenegre, J. (1959). Arch. Mal. Cour, 52, 639.

Wood, P. (1959). Pulmonary Circulation, ed. W. R. Adams and I. Veith. Grune and Stratton, New York. 